\title{
War and international trade: Impact of trade disruption on international trade patterns and economic development
}

\author{
Guerra e comércio internacional: Impacto da ruptura comercial nos \\ padrões de comércio internacional e desenvolvimento econômico
}

\author{
OLDRICH KRPEC* \\ VLADAN HODULAK**
}

\begin{abstract}
RESUMO: As rupturas dos fluxos comerciais decorrentes de conflitos militares levam a mudanças nas estruturas econômicas dos países, às mudanças subsequentes nas políticas comerciais e às mudanças nos padrões comerciais estabelecidos, com impacto na posição dos países no sistema de comércio internacional. Este artigo trata dos três conflitos do tempo moderno: guerras napoleônicas, a primeira guerra mundial e a segunda guerra mundial. Argumentamos que as mudanças resultantes da interrupção dos fluxos de comércio em si levam a mudanças e mudanças que são relativamente permanentes, independentes dos resultados dos conflitos para países individuais, e afetam significativamente regiões que não participaram do conflito.

PALAVRAS-CHAVE: História econômica; Comércio internacional; Conflitos militares; Industrialização; Política comercial.
\end{abstract}

ABSTRACT: The disruptions of trade flows due to military conflicts leads to changes in economic structures of countries, to the subsequent changes in trade policies, and to the changes of established trade patterns with impact on position of countries in international trade system. This paper deals with three modern time's conflicts: Napoleonic Wars, WWI and WWII. We argue that the changes resulting from the disruption of trade flows itself, leads to changes and shifts which are relatively permanent, independent on outcomes of the conflicts for individual countries, and do significantly affect regions which did not take part in the conflict.

KEYWORDS: Economic history; International trade; Military conflicts; Industrialization; Trade policy

JEL Classification: F13; F52; N70; O14.

\footnotetext{
* Department of International Relations and European Studies, Masaryk University, Brno, Czech Republic. E-mail: okrpec@gmail.com.

** Department of International Relations and European Studies, Masaryk University, Brno, Czech Republic. E-mail: hodulakv@gmail.com. Submitted: 20/June/2017; Approved: 27/April/2018.
} 
The connection among large military conflicts, changes in economic flows and the shifting position of states in international economic relations (along with the possible impact on the distribution of power) are all important issues from the viewpoint of international relations and international economics. Despite this, they are often seen as anomalous watershed events after which the world economy returns to "normal" operation. In this context, this paper describes the possible longterm effects military conflicts can have on the relative position of countries within the international economic system.

We believe it is possible to claim that the disruption of trade flows at the time of important military conflicts is an important source of change of world economy and position of individual countries and whole regions within.

Disruptions of trade flows are understood here as a side-effect of specific political and military objectives which are being followed during military conflicts, yet these disruptions of trade flows themselves are often neglected at the time. Nevertheless, these disruptions can potentially set in motion many important trends and therefore should be considered by those who create state policies. If disruptions of trade flows, changes in trade patterns, changes in socioeconomic institutions, and possibly changes in economic and political power are indeed interconnected - as is proposed in this paper - this interconnection should be the subject of scholarly analysis within the field of international relations and international politics.

The approach to the problem presented in this paper is a deductive one, using solid research and findings from economic history (i.e., Findlay, O'Rourke, 2006, 2007; Maddison, 2007; Davis 1979; Nye, 1991, 2007; Crouzet, 1964; Cain \& Hopkins, 1980; Aldcroft, 1977; Bairoch, 1982, 1989, 1996; Hardach, 1981). An attempt will be made to sketch the connection between the following factors: 1) disruption of established trade flows due to military conflicts; 2) changes in economic structures of the countries; 3 ) the subsequent change in trade policy; and 4) the possible impact of all these factors on the established trade patterns and potentially on distribution of the economic resources which underpin the political power. To describe these connections, three important modern times conflicts will be used: the French Revolutionary Wars, the Napoleonic Wars, and the War of 1812 between Britain and the United States; the First World War; and the Second World War, including its aftermath which took the form of the Cold War.

\section{CHANGES RESULTING FROM THE INTERRUPTION OF TRADE AND THE POTENTIAL IMPACT ON THE DISTRIBUTION OF POWER}

The basic premise of this text is simple, and its core argument derives from the empirical observations of number authors (Crouzet, 1964; Findlay \& O’Rourke, 2007; Maddison, 2007; Chang, 2007). Even though this thesis provides the opportunity to make some cautious generalizations, it has been formulated using specific historical examples and is based on the examination of concrete historical circumstances. These examples and circumstances result from historical processes where power (political, 
military, economic, or other) played an important role. The extensive use of political and military power leads to the creation of a specific form of trade system.

This trade system is - historically and simplified - composed of two types of subjects: of industrial countries and of commodity exporters (countries exporting raw materials, food, or colonial goods). The characteristic feature of the system is the existence of established trade patterns between the industrial country which exports industrial products and imports colonial goods, food, and other raw materials. At the same time, it is true that the country exporting industrial goods has considerable political and military power. This country controls the international division of labor and has vested interests in the current economic arrangement. In addition, it also understands its own industrial production as being causally related with wealth, military power, autonomy (and the ability to guarantee it), and with other values, such as prestige or with the ability to successfully carry out its "national project".

Countries exporting commodities and importing industrial goods often had no autonomy in terms of trade policy; or it was possible to take this autonomy away from them since they were a part of an empire, either a formal or an informal one. Such was the case of Latin America in the eighteenth century; of China, Japan, Egypt, Persia, and the Ottoman Empire in the second half of the nineteenth century; and of Africa during the nineteenth century. In addition, there were also states which simply abandoned all claims to political power and influence for specific reasons, such as having a small territory or due to specific geographical factors (e.g., entrepôt, a client state of a larger power). This was the case of Holland and Denmark in the nineteenth century; of city-states in South-East Asia; and of Singapore and of Hong Kong.

There certainly are historical examples of other types of economies. There were empires with a political system which rested on strict control of the land and population, and which engaged in international trade by exporting monopoly commodities. Here Russia, Poland, and Prussia can serve as examples. There were also independent countries which produced agricultural commodities and raw materials, exported them to international markets, and managed to ensure a high standard of living for their citizens. It is questionable, however, how stable (as many of them strongly pushed for industrialization) this model was when looked at from the viewpoint of economic history. The United States, Argentina, Australia, New Zealand, and Canada can be used as examples here.

There is logic of what happens when established trade flows are disrupted due to a military conflict. It is as follows: trade flows between both types of countries are disrupted or weakened. This can result from a measure imposed by the state for example when a trade is blockaded by an industrial country or by a rival, or when trade intermediated by neutral countries is banned or disrupted. It can also be an indirect result of war, for example when demand for imported goods (such as colonial commodities) drop in a country which switches to war-time economy. When a country switches its industry to war-time economy, exports of industrial products (which are exchanged for colonial goods) can also decline. The decline of trade in industrial and colonial goods impacts both sides.

The industrial country does not gain export revenues and does not import 
commodities. The price of food and of colonial goods on the domestic market rises and where this is possible, goods are produced domestically. When food imports are replaced by domestic production, revenues increase for agricultural producers who are otherwise not able to compete internationally. After the war ends, these producers demand protection from renewed imports.

What is crucial here, however, is the impact on the commodity exporter. It is hit hard both by the loss of export markets and by the falling prices of its exports (colonial goods can serve as a typical example) and also by the fact that industrial goods are unavailable and cannot be produced at home. The price of colonial goods drops, the price of industrial goods rises, terms of trade deteriorate, and in addition, physical capital (e.g., machinery for plantations and mines) is less readily available. All this is a strong incentive to replace the unavailable industrial imports with domestic products. It is impossible to create an industrial sector in any other way than by using the capital of the landowners who also wield political power since international loans are mostly unavailable during the conflict. This in turn alters the economic structure (generally from commodity export towards industry) as well as the preferences of the political elites (now engaged in industry) - from free trade to protectionism). When the conflict ends, infant industries must be protected from the return of advanced competitors. This is also connected to the fact of why an industrial country "fails" to guarantee the international division of labor - which it enforces or presents as mutually beneficial (idea of free trade).

Following the conflict, industrial economies have to face the competition of producers from non-industrial (i.e., "agricultural") countries and also have to face the protectionist measures of these economies. At home, they dealt with the redundant production capacities of the defense industry. At the same time, revenues from exporting manufactured goods are reduced and various factors (interruption of trade, disruption of production, higher demands of war-time economy) cause increased domestic agricultural production. This has two effects: 1 ) there is increased pressure to protect domestic agricultural products; and 2) there is a tendency to decrease imports of food due to the impact this can have on the country's balance of payments.

The non-industrial country exhibits similar tendencies: it protects its infant industry which demands protectionist measures against established competitors. In addition, since exporting food and raw materials is harder (or if their prices are low), it is necessary to replace imports with domestic production; this is also important with regard to the balance of trade and terms of trade. This means that a conflict generally strengthens the tendencies of both industrial and non-industrial countries to increase self-sufficiency, or rather to decrease their integration into the international trade system and their engagement in the international division of labor.

It is essential to emphasize that these tendencies result from the interruption of trade - which is itself a result of the military conflict. The basic mechanism is generally the same and does not depend on whether, for example, the non-industrial country actively joins the conflict, or whether the industrial country loses or wins the war. The basic claim is that the interruption of trade itself - and not the conflict as such or its specific outcome - affects the country's position in interna- 
tional economic - and thus also in political - relations. In other words, when assessing the potential or actual costs and benefits of a conflict, it is important to include not only the well-known and obvious factors, such as material and human losses, changes in political and military power, in prestige and sovereignty, or territories acquired and lost. Apart from these, it is important to consider the changes in the international division of labor which might include changes in specialization, in market shares, in access to markets, and in the distribution of know-how.

This paper looks at some of the most well-known conflicts of the modern era and using these examples, it attempts to identify the processes which significantly impacted the international economic and political system. Attention will only be paid to those aspects of these conflicts which are directly related to the problem at hand. First, the pre-conflict trade system will briefly be characterized; then, an attempt will be made to delimit to what extent and in what ways trade was disrupted by the conflicts; and finally, the consequences of this disruption for the post-conflict trade system will be described.

\section{THE FRENCH REVOLUTIONARY WARS, THE NAPOLEONIC WARS, AND THE ANGLO-AMERICAN WAR OF 1812}

The first conflict used to demonstrate how the interruption of trade could impact the distribution of power in the long run is a series of wars which started with the French Revolution in 1789 and ended with the Peace of Paris in 1815.

At the end of the eighteenth century, it was already possible to consider Britain to be the main world producer of industrial goods. It gained this position through series of important domestic socio-economic changes (i.e., industrial revolution) and by intensive use of political and military means in international environment. Trade and economic policies included strict protection of domestic infant industries (Findlay \& O'Rourke, 2007: 249; Nye, 2007: 20 ff.; Conybeare, 1987: 153; Chang, 2007: $45)$; high protective tariffs were imposed and imports of processed goods from mainland Europe and import of selected goods were often banned (the ban on imports of cotton cloth from Asia was particularly significant). Also important were a number of steps taken to stifle or to prevent the development of industry in British colonies. Navigation acts played an important role since they damaged the trade and commercial services of Britain's rivals, for example by providing Britain with trade revenues and thus strengthening the country's role in trade intermediation. In addition, navigation acts also meant that no effective competition to British domestic producers developed in the colonies since direct trade between the colonies and other countries was not possible: goods had to be re-exported through Britain and this of course meant additional revenues from customs duties (Davis, 1979: 42 ff.; Williams, 1990).

Britain was undergoing the process of industrialization and its key feature was factory-based mass production. The decisive role was played by the textile industry (which since the end of $18^{\text {th }}$ century specialized in cotton, substituting the traditional wool textiles as a main export product), but also by manufacturing engineer- 
ing, by the production of machines, and gradually by the production of vehicles and of other products related to transportation.

Industrial goods were exported to the European mainland and especially cotton fabrics, which was the key product of British factories at the time, had high competitive ability (Davis, 1979: 14-15, 37). British competition gradually forced countries in Western Europe (especially France, Switzerland, parts of present-day Germany, present-day Belgium) to change their economic policies. These countries used their resources and produced finished goods which required a high amount of manual labor but also manufactured luxury goods which were not suitable for factory-based mass production (Pollard, 1999: 59 ff.; Davis, 1979: 17-18). In addition, they developed industries which processed colonial goods (these goods were mostly British re-exports, except in France) and also focused on agricultural production. The fact that Britain dominated the cotton processing industry (which was the basis for development of many modern industrial sectors) was a serious obstacle to the industrialization of North America and of mainland Europe (Crouzet, 1964). It also meant - along with the intentional use of political and military means - that textile manufacturing collapsed in south and South-East Asia. These regions had provided the majority of manufactured goods as late as the beginning of the eighteenth century but later were effectively deindustrialized (Pollard, 1999: 87-88; Cain \& Hopkins, 1980).

Colonial goods (such as sugar, coffee, cocoa, tea, indigo, or tobacco) imported from Latin America, from the Caribbean, and from Asia also played an important role in international trade. A significant portion of British revenues came from reexporting these goods to the European mainland (Findlay \& O'Rourke, 2007: 327-328; Davis, 1979: $20 \mathrm{ff}$.). It was the attempt to acquire a share in this trade and to replace the imports of these goods which was behind the French attempts to build its own overseas empire. These attempts succeeded and many French ports on the Atlantic coast (and their industries) thrived as a result (Crouzet, 1964; Pritchard, 2004: 160 ff.; Butel, 1993: 161 ff.). However, the strongest position in re-export (included re-export of goods from the United States) was held by Britain.

At the end of the eighteenth century, countries on the European mainland produced agricultural goods (e.g., German states, Poland) and exported raw materials (e.g., Russia, Scandinavia, and the Baltic states). Britain was an important importer and consumer of these commodities. Some countries, such as Switzerland manufactured high-quality, handicraft-intensive items and other countries, for example Holland or Denmark, were well-known for their agricultural products with high added value (Pollard, 1999: 59, 63). France produced quality manufactured goods (e.g., silk, lace), agricultural products including those with high added value (wine or brandy), and processed colonial goods (e.g., sugar, rum, and tobacco). The United States produced traditional colonial commodities (sugar and tobacco) and became the largest exporter of raw cotton which became a key commodity as British industrialization continued (Davis, 1979: 14-17; Crouzet, 1964).

There were two main features of the conflict connected to the disruption of the trade system. The first was the British blockade of the European mainland. The 
second was the French-imposed ban on trade with Britain which later resulted in the Continental Blockade: the blockade was joined by French allies and by Frenchcontrolled states. Both events resulted in massive changes in relative prices of traded goods (see Table 1).

The British blockade of France and of its allies damaged industries which processed colonial goods since the French ports on the Atlantic coast were cut off from the Caribbean colonies. As a result, industry moved inland, mostly to the Rhineland, and re-oriented itself towards European markets (see O'Rourke, 2006). The Continental Blockade prevented British goods from entering most markets on the European mainland and had many consequences. Primarily, it meant that mainland economies were shielded from British industrial production and from the main component of British industry - from processed cotton fabrics. Cotton fabrics production and processing on the European mainland rose sharply during the war, mainly in France, in the German states, and in Switzerland. It subsequently stimulated additional industrial production in such sectors as manufacturing, metallurgy, engineering, and transportation (Crouzet, 1964; Davis, 1979: 17-18).

Table 1: Impact of Napoleonic Wars

(percentage increase in relative price above quadratic trend)

\begin{tabular}{|l|l|l|l|}
\hline Relative price & Country & War & Blockade \\
\hline Wheat/textiles & Britain & 19.03 & 41.35 \\
\hline Textiles/wheat & France & 16.58 & 19.84 \\
\hline Textiles/wheat & Germany & 6.74 & 5.71 \\
\hline Sugar/wheat & France & 63.31 & 195.03 \\
\hline Sugar/wheat & Germany & 2.43 & 143.09 \\
\hline Textiles/raw cotton & USA & 28.59 & 137.05 \\
\hline Cloth/silver & Peru & 12.92 & 91.58 \\
\hline Paper/silver & Peru & 53.19 & 120.79 \\
\hline
\end{tabular}

Source: O'Rourke, 2006.

Britain - due to the war - lost the traditional continental markets for its industrial products and also lost its sources of agricultural goods. This benefited land owners since land rents and grain prices rose (see Table 1). In addition, Britain imposed an embargo (1807) which prevented neutral countries from intermediation trade between Europe and the colonies. This meant that the United States was not able to use this opportunity to produce and export food and raw materials to continental Europe or to intermediate trade in colonial goods between Europe and nonEuropean regions (of course, trade between the United States and Britain continued). Instead, commodity prices dropped (O’Rourke, 2006; Davis, 1979: 44 ff.). This was an incentive to re-evaluate the structure of the economy and the falling prices of agricultural commodities contributed to the industrialization of New England.

The War of 1812 between Britain and the United States further reinforced the 
strategy of replacing British industrial products with domestic ones (see Table 2) and stimulated production which was oriented towards domestic markets. Since trade was interrupted, there was a strong motivation to redirect production capacities from export-oriented agriculture towards domestic industry. This appeared to be a long-lasting trend and it corresponded with changes in trade policies which shifted from preferring free trade to protecting domestic industry (Rosenbloom, 2002, see also Copeland, 1917).

Table 2: Cotton textile capacity in the US (thousands of spindles)
\begin{tabular}{|c|r|r|}
\hline & $\begin{array}{c}\text { Rosenbloom } \\
\text { Indices }\end{array}$ & $\begin{array}{c}\text { Ratio US/UK } \\
\text { (Rosenbloom) }\end{array}$ \\
\hline 1790 & 2 & 0.001 \\
\hline 1805 & 5 & - \\
\hline 1809 & 8 & 0.16 \\
\hline 1812 & 93 & 0.042 \\
\hline 1817 & 333 & 0.311 \\
\hline 1832 & 2,800 & 0.429 \\
\hline 1845 & 7,500 & 0.457 \\
\hline 1850 & 9,600 & 0.330 \\
\hline 1861 & 10,000 & 0.520 \\
\hline 1875 & 19,500 & 0.523 \\
\hline 1880 & 20,805 & 0.529 \\
\hline 1885 & 22,750 & 0.582 \\
\hline 1890 & 25,460 & 0,621 \\
\hline 1895 & 28,200 & \\
\hline
\end{tabular}

Source: Rosenbloom 2002. Protective tariff for cotton textiles introduced 1816, strengthened 1824 and 1828.

When imports of industrial goods from Britain started to be replaced by domestic products elsewhere (these were modern industrial sectors with high expansion potential), many groups which were engaged in industry strengthened their positions and gained more say in the formation of trade policies. The fact that the post-1815 regimes were not able to reverse the fundamental reforms of the Napoleonic era which were undertaken on territories occupied by the French (see Acemoglu \& Robinson, 2012: 289 ff.) also contributed to these changes. Thus, when British industrial exports returned after 1815 , other countries used trade policies which protected their domestic industries. In this way, the process of industrialization was started or significantly accelerated and bolstered in many countries (e.g., Germany, Switzerland, Belgium, and France). E.g., imports of industrial goods into France (woolen and cotton textiles) were completely banned until 1850s - afterwards France possessed developed textile industry and imports are therefore low (Nye, 1991). It became a model strategy for replacing imports (efficiently produced in another country) with domestic products using infant industry protection (Irwin, 1996: $116 \mathrm{ff}$.). Therefore, exports of British industrial products to mainland Europe fell (Davis, 1979: 88-89). 
On the other hand, the lobby of British landowners demanded protection of domestic agricultural production and was successful until the Corn Laws were abolished in 1846. Since it was difficult for British industrial products to succeed in Europe (Davis, 1979 15, 37 - see Table 4), there was a strong incentive to open non-European markets using political pressure and military power (Cain \& Hopkins, 1980). This was one of the cornerstones of the so called "liberal trade system" (1860s-1880s).

The wars generally decreased the importance of plantation colonies for European economies and also meant that revenues from re-exports of consumable colonial goods (unlike the raw materials) became less important (Davis, 1979: 90-91). During the nineteenth century, commodities from the temperate climate zones (be they food or raw materials) played a more important role. The fact that producers of colonial goods were in a delicate position became clear during the first decades of the twentieth century.

It is possible to say that many defeated countries in these wars (many German states, and gradually Holland, Belgium, and France) started or significantly reinforce the process of modernization and industrialization due to the economic impact of the military conflicts (see Table 3). The crucial moment came when the United States and many German states changed their traditional role as exporters of agricultural goods and turned into diversified economies with a fast-growing industrial sector.

Table 3: Per capita levels of industrialization (UK 1860=100)

\begin{tabular}{|c|c|c|c|c|}
\hline & 1750 & 1800 & 1830 & 1860 \\
\hline Belgium & 14 & 16 & 22 & 44 \\
\hline Netherlands & - & 14 & 14 & 17 \\
\hline Sweden & 11 & 13 & 14 & 23 \\
\hline UK & 28 & 30 & 39 & 100 \\
\hline France & 14 & 14 & 19 & 31 \\
\hline Italy & 13 & 13 & 13 & 16 \\
\hline Portugal & - & 11 & 11 & 13 \\
\hline Spain & 11 & 11 & 13 & 17 \\
\hline Austria-Hungary & 11 & 11 & 13 & 17 \\
\hline Germany & 13 & 13 & 14 & 23 \\
\hline Russia & 9 & 9 & 11 & 13 \\
\hline Switzerland & 11 & 16 & 25 & 41 \\
\hline Europe & 13 & 13 & 17 & 27 \\
\hline Canada & - & 5 & 7 & 46 \\
\hline US & 4 & 9 & 21 & 126 \\
\hline Japan & 7 & 7 & 7 & 20 \\
\hline China & 8 & 6 & 4 & 3 \\
\hline India & 7 & 6 & 3 & 2 \\
\hline Brazil & - & - & 4 & 7 \\
\hline Mexico & - & - & 5 & 7 \\
\hline
\end{tabular}

Sources: Bairoch, 1982; Broadberry and O'Rourke 2010: 172, 212. 
The unquestioned military victory of Britain strengthened its economic and political power. Consequently, a trade pattern was enforced which is known today as the "North-South Model". This means that industrial products were exported into non-European regions and food, raw materials, and colonial goods were imported from these regions. The establishment of this system, however, had little in common with the division of labor according to the efficiency of production since the system resulted from extensive use of power following different goals (see Cain \& Hopkins, 1980). International division of labor compatible with the comparative advantage theory was thus enforced in Asia, in Africa, in the Middle East, and - due to the privileged position of Britain after the defeat of Spain - in Latin America. However, trade with Western Europe was much different. Britain here (re)exported primarily raw materials and colonial goods, and imported continental industrial products. That was going against the logic of comparative advantage and was to a large extent the result of industrialization and perfectionistic policies established during and after the conflict. Countries which retained independent trade policies accepted relatively free trade only when it no longer meant acceptance of abovementioned international division of labor (i.e., the "North-South Model") - thus, after they industrialized.

\section{THE FIRST WORLD WAR}

The trade system before the outbreak of the First World War had several key features. Britain was an important importer of food and raw materials from the "western offshoot" (the United States, Canada, New Zealand, Australia; see Maddison, 2007) (see Yates, 1959: 226-232). These countries replaced eastern European states and the Baltic region as the main sources of these commodities during the nineteenth century (Bairoch \& Kozul-Wright, 1996). Still important were British re-exports of raw materials to the European mainland and exports of British manufactured goods to the empire - both the formal one (India, parts of South-East Asia and Africa) and to the informal one, i.e., to areas where Britain had strong political influence and privileged markets - China, the Ottoman Empire, Egypt, Persia, Latin America.

The largest industrial economies on the European mainland (France, Germany) continued to protect their markets from both industrial and (at least from the 1880s) also from agricultural imports. Their exports were aimed primarily at Europe and Britain was an important destination, maintaining a free port policy. Continental powers (including also Italy and to some extent Holland) were building and maintaining their own empires. Within these, the colonial division of labor was the norm and imports of rivals were discriminated against. Small European countries (such as Switzerland, Belgium, Holland, or Denmark) in general accepted the necessity of relatively liberal trade policies (e.g., during the trade war between Switzerland and France between 1892 and 1895; see Conybeare, 1987: 188-191) and also accepted the fact that protectionist measures were used by the great pow- 
ers. They focused on high added value and on high-quality agricultural and industrial products.

Table 4: Trade during the Great War: 1913=100 (current prices)

\begin{tabular}{|c|c|c|c|c|c|c|c|c|c|c|}
\hline & \multicolumn{2}{|c|}{$\begin{array}{c}\text { Austria- } \\
\text {-Hungary }\end{array}$} & \multicolumn{2}{|c|}{ France } & \multicolumn{2}{c|}{ Germany } & \multicolumn{2}{c|}{ Russia } & \multicolumn{3}{c|}{ UK } \\
\cline { 2 - 12 } & IMP & EXP & IMP & EXP & IMP & EXP & IMP & EXP & IMP & EXP \\
\hline 1913 & 100 & 100 & 100 & 100 & 100 & 100 & 100 & 100 & 100 & 100 \\
\hline 1914 & 85 & 75 & 76 & 71 & 79 & 73 & 80 & 63 & 91 & 82 \\
\hline 1915 & 110 & 48 & 131 & 57 & 66 & 31 & 83 & 27 & 114 & 73 \\
\hline 1916 & 174 & 56 & 245 & 90 & 78 & 38 & 178 & 38 & 129 & 96 \\
\hline 1917 & 145 & 61 & 327 & 87 & 66 & 35 & 169 & 31 & 151 & 100 \\
\hline 1918 & 108 & 56 & 265 & 69 & 66 & 47 & - & - & 191 & 96 \\
\hline $1919 *$ & - & - & 425 & 173 & - & - & - & - & 222 & 152 \\
\hline
\end{tabular}

*Austria-Hungary 1919 figure: for ten month only.

\begin{tabular}{|c|c|c|c|c|c|c|c|c|c|c|c|c|}
\hline & \multicolumn{2}{|c|}{ Argentina } & \multicolumn{2}{|c|}{ Canada } & \multicolumn{2}{|c|}{ US } & \multicolumn{2}{|c|}{ India } & \multicolumn{2}{|c|}{ Japan } & \multicolumn{2}{c|}{ China } \\
\cline { 2 - 13 } & IMP & EXP & IMP & EXP & IMP & EXP & IMP & EXP & IMP & EXP & IMP & EXP \\
\hline 1913 & 100 & 100 & 100 & 100 & 100 & 100 & 100 & 100 & 100 & 100 & 100 & 100 \\
\hline 1914 & 65 & 78 & 74 & 101 & 84 & 94 & 100 & 88 & 84 & 94 & 100 & 88 \\
\hline 1915 & 62 & 112 & 82 & 171 & 80 & 111 & 80 & 103 & 80 & 111 & 80 & 103 \\
\hline 1916 & 74 & 110 & 137 & 259 & 111 & 172 & 91 & 120 & 111 & 172 & 91 & 120 \\
\hline 1917 & 77 & 106 & 156 & 349 & 151 & 245 & 96 & 115 & 151 & 245 & 96 & 115 \\
\hline 1918 & 101 & 154 & 149 & 279 & 239 & 302 & 97 & 121 & 239 & 302 & 97 & 121 \\
\hline 1919 & 132 & 199 & 152 & 284 & 315 & 332 & 114 & 157 & 315 & 332 & 114 & 157 \\
\hline
\end{tabular}

Source: Calculated from Findlay and O'Rourke, 2007: 432.

North America still exported food and raw materials, but also continued the process of industrialization oriented towards the domestic market (Bairoch \& Kozul-Wright, 1996). The United States was free riding on a system of agreements which regulated the rates of protection in international trade (Conybeare, 1987: 252). Many developing economies were still linked to the trade system by exporting colonial goods - under conditions set by the colonial administration. Where countries managed to keep formal independence, changes in economic structure - and thus also in export patterns - were prevented by "unequal" treaties, such as those Britain signed with Egypt, Persia, China, and with the Ottoman Empire (see Pollard, 
1999: 87-88). Some economies which lost independent trade policies (most notably China and India, but also states in the Middle East) were previously important exporters of manufactured goods (Findlay \& O'Rourke, 2007: 324; Cain \& Hopkins, 1980).

Japan is an exception to the rule since, despite the fact that it was forcibly integrated into the "free" trade system, it quickly started industrializing and modernizing. These developments resulted from political changes (far-reaching liberal reforms of the political system after the Meiji Restoration of 1869; see Acemoglu \& Robinson, 2012: 296-297) and from modernization and centralization of the state in the face of the growing power of western countries (which led to the opening up of China and Japan). Another reason might have been that Japan lacked a "natural" (i.e., colonial) commodity suitable for export (Jansen, 1995: 126).

The First World War differed from other European conflicts also due to the extent to which it aimed to disrupt international trade (see Table 4). The goal of the opposing sides was to prevent the import of food and of raw materials, and not only to prevent the enemy from gaining export revenues, which was the predominant goal in previous wars. The transformation to war-time economy was unprecedented and the role played by the state in the coordination of industrial activities rose dramatically (Verdier, 1994: 152-153; Tilly, 1990: 99 ff.). This was connected with the fact that factors of production were relocated to industrial war-time production and also that they shifted from overseas exports (which were used to pay for colonial goods) to the immediate demands of the war-time economy.

When the supply of industrial goods to Latin America and to Asia was interrupted, this had significant long-term effects (see below). The weakening or interruption of exports from Western Europe to the regions of the "Western offshoot" also played a significant role. British and French imports from these countries, however, did not decrease in any significant way (Findlay \& O'Rourke, 2007: 430433) (see Table 5) and one of the results was the accumulation of an enormous debt, primarily to the United States.

The interruption of exports of European industrial goods to Latin America is particularly interesting. E.g., Brazil cotton cloth imports decreased from 3,631 tons to 1,092 tons between 1913 and 1915 (Hardach, 1977: 271). It was connected with a decreasing demand for colonial goods and at the same time with a rising demand for food and raw materials from temperate climate zones. Direct foreign investments into agriculture and mining had to be written off by Western Europe (Thorp, 1998: 98-100; Baer, 1972). Countries of Latin America were thus motivated to replace European imports with domestic production or with imports from the United States (see Eichengreen \& Irwin, 1998) and to shift to agricultural products grown in temperate climate zones where this was possible. The economies of Canada and of Australia were in a similar situation to that of the United States during an earlier period. The British administration granted these countries significant autonomy in regard to trade policies, one of the reasons being the great extent to which they had 
participated in the First World War. The states of the "western offshoot" started the process of industrialization (i.e., in general replacing British industrial imports), regardless of the comparative advantage they had in agricultural production. The United States of course had no reason to change their existing policies (high protection of domestic industries) due to the ongoing conflict (Conybeare, 1987: 234).

An important moment came when the exports of manufactured goods from Europe to Asia were interrupted. Japan used this opportunity and significantly increased the quantity of its industrial exports into the "vacated" Asian markets (see Aldcroft, 1977). According to Hardach (1977: 261) the exports of finished manufactures increased its share in exports from 29 to 44 percent between 1913 and 1918, while its share in imports decreased from 17 to 10 percent. Important and permanent changes began when European political influence in these regions weakened. To a certain extent, these changes were also fuelled by the fact that an Asian economy (i.e., Japan) was able to reach the industrial phase along with all the consequences - gaining political independence, cultural emancipation, and a share of political power within the international system. Precisely at this moment, India and China rejected the existing trade patterns (whether they resulted from specialization according to the logic of comparative advantage or from the use of political and military power). Both countries significantly increased tariffs and attempted to start the process of (re)industrialization (see Baer, 1972; Maddison, 2007: 118). According to Fong the number of cotton spindles in China quadrupled between 1914 and 1925 as a direct result of sharp decline in foreign imports due to war (Fong, 1932).

The impact of the conflict on the international trade system was enormous. Europe had unused surplus capacities in the defense industry and the producers wanted protection against foreign competitors. After the war, the most efficient producer were the United States. This resulted from the fact that a significant part of European industry changed from export-oriented to import-competing and this in turn impacted trade policy preferences. The fact that a country's preference for free trade and for the international division of labor was determined by the specific position of the given country (i.e., by its comparative ability and by market-conformist specialization in industrial production) was clearly demonstrated by the shift of British policy from free trade to some protection between wars (Irwin, 1995).

Of equal importance was the renewal of European agricultural production capacities after the war (Findlay \& O'Rourke, 2007: 436). European agricultural producers faced imports from non-European destinations and falling prices and logically demanded the protection of domestic markets. Governments were willing to grant this protection. One of the reasons was that food purchases (using scarce international money) were often undesirable due to external debt. Spending hard currency was preferable only to buy certain industrial and capital goods which were not produced by the domestic economy.

This meant that pre-war trade patterns and the international division of labor 
were significantly re-evaluated. The countries of the "western offshoot" - increasing production of food and raw materials in reaction to European demand - also had difficulties dealing with the new situation. When commodity prices fell, revenues fell as well (mostly in the United States) and farmers had difficulties repaying their loans to domestic banks. This significantly contributed to the Great Depression later (Nye, 2009). The demands of domestic producers for the protection of markets from foreign imports were understandable. Thus, there was one additional incentive to industrialize and to use domestic production to replace the European industrial exports which were cut off by the war.

The falling prices of agricultural commodities after the war and of raw materials during the Great Depression meant that the economic and export structure was further revised. There was a shift away from agricultural exports and towards domestic markets and thus towards a greater amount of domestically produced industrial goods. The systemic change was complete when these types of goods significantly increased within overall US exports.

After the war, the United States became undoubtedly the strongest economy. Like Britain a century earlier, the United States developed its superiority in an era where many changes were set in motion - considerable number of them significantly related to the phenomena under discussion: the interruption of trade patterns by a war. But these changes (taking place mainly in non-European economies) were not to be fully felt for another fifty years.

\section{THE SECOND WORLD WAR}

When the Second World War broke out, the trade system was characterized by a general effort to maximize exports of both industrial and agricultural goods, typically by devaluating currency or by using targeted subsidies. These efforts were supplemented by the protection of domestic markets from imports and by attempts at price support.

This situation in the international economic system was particularly difficult for the indebted European countries, one of the reasons being that the volume of available international loans was shrinking (Foreman-Peck, 1999: 140 ff.). Producers of colonial goods attempted to reorient their economies. Exporters of food and raw materials from Latin America were trying to isolate their own economies from the world economy, doing this not only through tariffs and quotas, but also by refusing to repay their foreign debts. Given the circumstances, this strategy can be considered to have been relatively successful (Clemens \& Williamson, 2004).

The United States continued with strong protectionist policies and attempted to isolate the domestic markets from imports of industrial and - newly also - agricultural goods. US therefore finished transformation of its economic structure and became the largest exporter of industrial goods in the world. Consequently, it was 
threatened by retaliations from other industrial countries since industrial imports, unlike those of agricultural goods or of raw materials, traditionally faced much higher barriers. This led the United States to enter into a system of trade agreements (Reciprocal Trade Agreements Act, 1934). However, the general aim was rather to improve US access to foreign markets in exchange for minimal concessions while taking full advantage of the size of its own economy and political power (Eckes 1999: 140-142).

Britain reacted to the loss of its industrial superiority by protecting its domestic markets using tariffs and later by devaluating its currency (Findlay \& O'Rourke 2007: 430-431; Irwin, 1996: 189 ff.). Another important way the British supported their own industry was by focusing on the privileged markets of the Commonwealth. The most important Commonwealth economies (Canada, Australia) had independent trade policies and attempted to support industrialization at home by protecting their domestic markets (see Bairoch, 1989: 42; Findlay \& O'Rourke, 2007: 403, 444). When Britain wanted to open its markets to agricultural products (and in exchange wanted access to the markets of the Commonwealth), it met with resistance. The British economy gained only a indirect concessions when Commonwealth countries increased the protection of their markets against non - Commonwealth states and an analogous situation existed in terms of Commonwealth products entering British markets (Conybeare, 1987: 239).

This development corresponded with the attempts of other great powers to create privileged trade blocs. Germany attempted to create a regional division of labor within central and Eastern Europe - to export industrial goods and import raw materials and food. France focused on its colonial empire and Italy attempted to create its own one (Aldcroft, 1999: 156-157). In all these cases, the great powers aimed to open their markets to regulate volume of imports of food and of raw materials and to acquire access to markets within their bloc where their industrial products could be sold. This resulted in a fragmentation of the trade system and it had - together with the coming conflict - important consequences.

In Asia, Japan radically strengthened its position, both by penetrating regional markets and by imperial aggression. This aggression was to some extent fueled by strict British and American measures to protect their markets (these measures were aimed specifically against Japanese industrial exports), by the fact that Japan lacked raw materials, and because the Japanese population was growing rapidly (this last trend was partly related to US immigration policy aimed against Japan) (Rothermund, 1996: 115: ff.).

It was inevitable that the war totally paralyzed international trade. The shift to war-time economies, blockades, unrestricted submarine warfare, and a massive United States concession program to support its allies, meant that trade flows were substantially disrupted. Foreign trade was clearly subordinate to security policy and basically controlled by the state. An important role was played by forced 
transfers of people and of resources within the German sphere of influence (see Aldcroft, 1999: 160-164).

Britain reduced the commercial exports of all commodities, imported large quantities of goods primarily from the United States, including industrial products, food, and raw materials. It also broke off trade and commercial relations with its informal empire and to a certain extent also with its formal one. The massive integration of Commonwealth economies into the war effort foreshadowed the radical strengthening of their autonomy after the war. France and Holland lost their empires which were mostly taken over by Japan. After the conflict, it was obvious that the economic center moved from Western Europe to North America and the process was now complete (see Maddison, 2007).

Accepting free trade after war meant that Western Europe would have to abandon its industrial base and this was of course unacceptable (cf. Verdier, 1994: 202). The international division of labor based on the logic of comparative advantage (i.e., on economic efficiency) was totally out of the question in a situation where western Europe was not an efficient producer, either in relative or in absolute terms (Lynch, 1984). Britain and France initiated state-controlled programs to save, support, and restructure their industries. Economic policies were primarily aimed at domestic economies. Foreign trade was subordinate to the national interest - to acquire international currency and use it to purchase capital goods from the United States which in turn would be used to support domestic industry (Eichengreen, 2007: 59-60).

The often-mentioned liberalization of the Atlantic trade resulted mostly from unilateral efforts made by the United States and was only possible due to the fact that trade policy was subordinate to foreign and security policies (Eckes, 1999: $169 \mathrm{ff}$.).

Since the reconstruction of Europe was identified as a US strategic interest, the autonomous policies of European countries (i.e., such policies which would isolate their domestic economies from the world economy) were accepted as a given and tolerated by the United States. The pressure to gradually liberalize trade in Western Europe was accompanied by a generous program which would help to eliminate balance of payments constraints (Eichengreen, 2007: 79-80). Another precondition was to allow European exports into US markets. This meant that European exports were soon directed outside Europe and this lowered the political friction on the continent. The plan to de-industrialize Germany was quickly abandoned and a country with no physical capital and with a very limited amount of financial capital was soon on its way to once again becoming one of the leading industrial powers. The United States adopted the same generous attitude towards Japan - who continued the process of rapid industrialization with limited attention paid to the liberal recommendations for suitable development and trade policy (see Samuels, 1996).

The growing commercial exchange between the United States on the one hand and between Western Europe and Japan on the other is often interpreted as liberalization of international trade. However, this is a misleading interpretation. Liberal international trade system consisted only of North America, Western Europe, 
and to some extent by Japan. Other regions reacted differently to the breakdown of international trade: local economies were restructured and trade policies were seriously reconsidered.

Until the end of the twentieth century, economies in Latin America and south, south-east, and East Asia developed according to the following model: autonomous industrialization was undertaken and foreign trade was strongly regulated by the state (Bulmer-Thomas, 2003: $320 \mathrm{ff}$.). The disruption of trade patterns by the world wars meant that programs were undertaken to replace western imports with domestic production where this was possible. This was accompanied by strong emancipatory nationalism and by the fact that industrial and trade policies were subordinated to the goal of attaining political and economic independence as well as a power-share in the international system (see Landes, 1999: $472 \mathrm{ff}$.$) .$

Table 5: Changes in the structure of the economies (percentage distribution of gross domestic product according to principal sectors)

\begin{tabular}{|l|c|c|}
\multicolumn{1}{|c}{ Argentina (1960 prices) } \\
\hline Agriculture & $1927-1929$ & $1963-1965$ \\
\hline Oil and mining & 27.4 & 17.1 \\
\hline Manufacturing & 0.3 & 1.5 \\
\hline Construction & 23.6 & 33.7 \\
\hline
\end{tabular}

Brazil (1953 prices)

\begin{tabular}{|l|c|c|c|c|c|}
\hline & $1939^{*}$ & 1947 & 1953 & 1960 & 1968 \\
\hline Agriculture & 25.8 & 30.0 & 26.1 & 22.2 & 20.5 \\
\hline Industry & 19.4 & 20.6 & 23.7 & 28.0 & 29.3 \\
\hline Other & 54.8 & 49.4 & 50.2 & 49.8 & 50.2 \\
\hline
\end{tabular}

*1939 figure: current prices.

\begin{tabular}{|c|c|c|c|c|c|c|}
\hline & 1900 & 1910 & 1930 & 1940 & 1950 & 1960 \\
\hline Rural & 34.6 & 27.9 & 25.9 & 24.3 & 22.5 & 18.9 \\
\hline Extractive & 6.4 & 9.1 & 13.5 & 8.5 & 5.7 & 5.4 \\
\hline $\begin{array}{l}\text { Commerce and } \\
\text { transportation }\end{array}$ & 23.4 & 23.4 & 23.4 & 28.5 & 31.0 & 30.6 \\
\hline $\begin{array}{l}\text { Manufacturing, } \\
\text { construction and } \\
\text { electricity }\end{array}$ & 13.2 & 13.7 & 16.7 & 22.6 & 24.5 & 30.6 \\
\hline
\end{tabular}

Source: Baer, 1972. 
While political relations between many developing countries and western states were cooperative, great efforts were made to fundamentally revise historical economic ties. Industrial capacities were built even if no favorable conditions were really present. The steel industry in South Korea might serve as an example: it lacked physical, financial, and human capital as well as natural resources (see Chang, 2007: 109). Only imports of capital goods from the West were supported, meaning goods which were connected with the development of the industrial base. The aim was to replace basically all kinds of western imports. Investments were welcome only if they provided technologies and know-how needed by the developing economies.

The larger Latin American economies substituted industrial imports by domestic production with considerable success (see Table 5) until the neoliberal turn in world economy in 1980s (Bértola \& Ocampo, 2012: 200 ff.). The model of SouthEast Asia sought to coordinate (by deliberate government effort) the resources of a strongly pro-export policy and subsequently to strategically liberalize trade (see Haggard, 1990). But both these models followed the same goals and, in both cases, changes took place to socioeconomic institutions.

These changes were related to the disruption of established trade patterns during "European" conflicts and seem to be permanent and irreversible (an analogy with Germany after WWII can be made here). Not even the bankruptcy of Latin American economies and the subsequent structural adjustments - which strongly pressured these economies to reorient themselves in accord with neoclassical attitudes towards the international division of labor - were able to reverse the process of industrialization.

\section{CONCLUSIONS}

Military conflicts interrupted established trade flows and significantly changed the international division of labor. This had (potential) long-term consequences for the distribution of economic, political, and military power. In addition, the position of many countries within the economic system was eroded despite the fact that they had come out as victors in the conflict (Britain, countries of western European, and the United States might serve as examples here).

On the other hand, in many cases there were changes which can be seen as having a positive impact in the long run, i.e., gaining or strengthening a share of political or economic power within the international system. Many of the countries which experienced these trends were among those who lost in the conflict (France, Germany).

Other countries, which gradually strengthened their position, did not actively participate in the conflict at all. They were affected since they were cut off from supplies of goods for which they did not have domestic substitutes. And such a 
situation is generally seen as a threat - after all, blockades and embargos (as standard tools of foreign and security policies) are used in order to create precisely this kind of situation.

The effects of the two world wars in non-European regions (Latin America and South, South-east and East Asia) are particularly important. Processes were started which significantly impacted the distribution of economic and of political power and these issues were one of the most discussed topics at the end of the twentieth century.

In this connection it is important to stress that it would be misleading to interpret the current trade system (since the late $20^{\text {th }}$ century) as a final triumph of liberal ideas. In no way is it true that the idea of the international division of labor according to the comparative advantage (i.e., according to maximum efficiency of production) has been put into practice. The growth of trade in the twentieth century resulted to a large extent from the fact that - due to the Cold War - the hegemonic power was willing to accept imports of its allies who at the same time carried out independent strategies of economic reconstruction and development.

This relatively liberal international trade was joined by those countries which already possessed a developed industrial base. This was the case not only for western European countries but also for Japan. Individual countries often stayed outside the system until they possessed a developed industrial base; often using independent and non-cooperative industrialization strategies to achieve this goal (the state played an important part and the economy was publicly coordinated).

However, the growth of trade after WWII did not mean that the "liberal" order of the nineteenth century returned. Nor did it mean that it was superseded. The fact that the important newly industrialized countries (NICs) were integrated into the trade system was the outcome of long-term trends which were in turn to significant extent caused by the disruption of trade during periods of external shock (i.e., during military conflicts).

\section{REFERENCES}

Acemoglu, D., Robinson, J. (2012) Why Nations Fail: The Origins of Power, Prosperity, and Poverty. Random House Digital, Inc.

Aldcroft, D. H. (1977) From Versailles to Wall Street, 1919-1929. Berkeley: University of California Press.

Baer, W. (1972) "Import substitution and industrialization in Latin America: experiences and interpretations", Latin American Research Review, 7(1): 95-122.

Bairoch, P. (1982) "International industrialization levels from 1750 to 1980", Journal of European Economic History, 2(11): 269-331.

Bairoch, P. (1989) "European trade policy, 1815-1914”, The Cambridge Economic History of Europe, 8(1): 160-180.

Bairoch, P., Kozul-Wright, R. (1996, March) Globalization Myths: Some Historical Reflections on Integration, Industrialization and Growth in the World Economy. New York: United Nations Conference on Trade and Development. 
Bértola, L., Ocampo, J. A. (2012) The Economic Development of Latin America since Independence. Oxford: Oxford University Press.

Broadberry, S., O'Rourke, K. H. (2010). The Cambridge Economic History of Modern Europe: Volume 2, 1870 to the Present. Cambridge: Cambridge University Press.

Bulmer-Thomas, V. (2003). The Economic History of Latin America since Independence. Cambridge: Cambridge University Press.

Butel, P. (1990) "France, the Antilles, and Europe in the seventeenth and eighteenth centuries: renewals of foreign trade". The rise of merchant empires: long-distance trade in the early modern world, 1350-1750. Cambridge: Cambridge University Press.

Cain, P. J., \& Hopkins, A. G. (1980) "The political economy of British expansion overseas, 17501914", The Economic History Review, 33(4): 463-490.

Chang, H. J. (2007) Bad Samaritans: Rich Nations, Poor Policies, and the Threat to the Developing World. New York: Random House Business.

Clemens, M. A., Williamson, J. G. (2004) "Why did the tariff-growth correlation change after 1950?", Journal of Economic Growth, 9 (1): 5-46.

Conybeare, J. A. (1987). Trade Wars: The Theory and Practice of International Commercial Rivalry. Washington D.C.: Columbia University Press.

Copeland, M. T. (1917) The Cotton Manufacturing Industry of the United States (Vol. 8). Harvard: Harvard University Press.

Eckes, A. E. (1999) Opening America's Market: US Foreign Trade Policy since 1776. Chapel Hill: University of North Carolina Press.

Davis, R. (1979) The Industrial Revolution and British Overseas Trade. Leicester: Leicester University Press.

Deutsch, K. W., Eckstein, A. (1961) "National industrialization and the declining share of the international economic sector, 1890-1959", World Politics, 13(02): 267-299.

Eichengreen, B. (2007). The European Economy Since 1945: Coordinated Capitalism and Beyond. Princeton: Princeton University Press.

Eichengreen, B., Irwin, D. A. (1998) The Role of History in Bilateral Trade Flows. Chicago: University of Chicago Press.

Findlay, R., O'Rourke, K. H. (2007) Power and Plenty: Trade, War, and the World Economy in the Second Millennium. Princeton: Princeton University Press.

Fong, H. D. (1932) "Cotton industry and trade in China". Chinese Soc. \& Pol. Sci. Rev., 16: 347-365.

Foreman-Peck, J. (1999) “The zenith of European power 1870-1918”. In D.H. Aldcroft and A. Sutcliffe, Europe in the International Economy 1500-2000, p. 102-129.

Hardach, G. (1981) The First World War, 1914-1918 (Vol. 2). Berkeley: University of California Press. Irwin, D. A. (1995) "Multilateral and bilateral trade policies in the world trading system: An historical perspective”. In De Melo, J., \& Panagariya, A. (eds.). New Dimensions in Regional Integration. Cambridge University Press. 90-121.

Irwin, D. A. (1996) Against the Tide: An Intellectual History of Free Trade. Princeton: Princeton University Press.

Jansen, M. B., ed. (1995) The Emergence of Meiji Japan. Cambridge: Cambridge University Press.

Krasner, S. D. (1976) "State power and the structure of international trade", World Politics, 28(03): 317-347.

Maddison, A. (2007) A Millennial Perspective (vol. 2): Historical statistics. Paris: OECD.

Nye, J. V. (1991) "The myth of free-trade Britain and fortress France: tariffs and trade in the nineteenth century", Journal of Economic History, 51(1): 23-46.

Nye, J. V. (2007) War, Wine, and Taxes: The Political Economy of Anglo-French Trade 1689-1900. Princeton: Princeton University Press.

Nye, J.V. (2009) "The depression and the failure of impersonal trust: What have we really learned from the great depression?” Mercatus Center, No. 09-31 (August 2009), George Mason University.

O’Rourke, K. H. (2006) “The worldwide economic impact of the French Revolutionary and Napoleonic Wars, 1793-1815" Journal of Global History, 1(01): 123-149.

Pollard, S. (1999) “The Europeanization of the international economy 1800-1870". In. Aldcroft D.H. and A. Sutcliffe, Europe in the International Economy, 1500: 50-102. 
Pritchard, J. (2004) In Search of Empire: The French in the Americas, 1670-1730. Cambridge: Cambridge University Press.

Rosenbloom, J. L. (2002). Path Dependence and the Origins of Cotton Textile Manufacturing in New England. National Bureau of Economic Research W9182.

Statistisches Jahrbuch für das Deutsche Reich 1923, Vol. 45. Berlin.

Statistisches Jahrbuch für das Deutsche Reich 1927, Vol. 49. Berlin.

Thorp, R. (1998) Progress, Poverty and Exclusion: An Economic History of Latin America in the 20th Century. Inter-American Development Bank.

Verdier, D. (1994) Democracy and International Trade: Britain, France, and the United States, 18601990. Princeton: Princeton University Press.

Williams, B. (1990). "The foreign policy of England under Walpole”, The English Historical Review, 15(58): 251-276.

Yates, P. (1959) Forty Years of Foreign Trade: A Statistical Handbook with Special Reference to Primary Products and Under-developed Countries. London, GB: G. Allen \& Unwin. 